\title{
An infertile case of $47, X Y Y$ syndrome without autistic spectrum: Cost effective well-define of extra $Y$ chromosome by GTG, C bandings, QF-PCR and FISH analyses
}

\section{Otistik bulguları olmayan infertil 47, XYY olgusu: Ekstra Y kromozomun GTG, C bantlama, QF-PCR ve FISH analizi yöntemleri ile etkin ve doğru tespiti}

Özturk Özdemir ${ }^{1}$, Barış Paksoy ${ }^{1}$, Atilla Gürgen², Mine Oruç ${ }^{1}$, Onur Yıldız ${ }^{1}$, Diğdem Uysal $^{1}$, Ahmet Uludağ ${ }^{1}$, Fatma Silan ${ }^{1}$

${ }^{1}$ Department of Medical Genetics, Faculty of Medicine, Canakkale Onsekiz Mart University, Canakkale, Turkey ${ }^{2}$ Department of Psychiatry, Faculty of Medicine, Canakkale Onsekiz Mart University, Canakkale, Turkey

Corresponding author: Prof. Dr. Ozturk OZDEMIR, PhD, Canakkale Onsekiz Mart University, Faculty of MedicineDepartment of Medical Genetics, Canakkale / TURKEY

E-mail: ozdemir615@yahoo.com

Received/Accepted: February 08, 2016/ July 17, 2016

Conflict of interest: There is not a conflict of interest.

\section{SUMMARY}

The Autism Spectrum Disorders (ASD) was frequently reported in autosomal and sex chromosome abnormalities and limited findings pointed out the Y chromosome. In the current case, it was aimed to identify the genetic cause for a man without autism profiles using combined cytogenetic and molecular genetic techniques.

Automated karyotype analysis was made after combined methods with GTG, C bandings, QF-PCR and FISH techniquesfor the current case. Additional Y chromosome was identified after conventional GTG and C-banded karyotype analysis.

The current case of 47,XYY syndrome was reported due to without autistic profiles such as language and social impairment. The proband's karyotype was determined as 47,XYY. No other numerical and/or structural chromosomal abnormalities were detected in the karyotype analysis.

Cytogenetic methods combined with cost-effective techniques such as C, GTG banding and FISH provide well-define of extra Y chromosome in the presented case of without autistic spectrum. Both $\mathrm{Y}$ chromosomes were in the same size and C-banded profiles in the current proband pointed out that both are originated from one chromosome by endoreduplication $\mathrm{Y}$ chromosome after zigot formation

Keywords: Super-male syndrome; 47, XYY karyotype; without autistic spectrum; cost effective diagnosis 


\section{ÖZET}

Otistik spektrum bozukluklarının, otozomal ve seks kromozom bozukluklukları ile birlikteliği birçok kez rapor edilmekle birlikte sınırlı sayıda literatür bilgisi Y kromozomunu işaret etmektedir. Biz bu sunumda sitogenetik ve moleküler genetik tekniklerinin birlikte kullanımı ile otistik bulguları olmayan bir super-erkek olgunun doğru ve etkin tanı almasının önemini raporlamayı amaçladık. Bu olguda, lenfosit hücre kültürü ile elde edilen metafaz örnekleri GTG, C bantlama, QF-PCR ve FISH yöntemleri ile otomatik karyotiplemeleri yapıld1.

Dil ve sosyal işlev bozuklukları gibi otistik spektrum bulguları olmayan olgumuzun sitogenetik ve moleküler genetik analizler sonrasında ekstra Y kromozomu taşıdığı ve 47,XYY(super-erkek) karyotipinde olduğu anlaşılmıştır. Olgunun, yapılan ayrıntılı karyotip analizinde başka bir sayısal ve/veya yapısal kromozom anomalisine rastlanmamıştır.

Olgunun sahip olduğu ekstra Y kromozomu, GTG, C bantlama, FISH ve QF-PCR teknikleri birlikte kullanılarak hastanın etkin ve doğru tanı alması sağlanmıştır. Olguda saptanan her iki Y kromozomun benzer boyut ve C bant paterninde olmasi, ekstra Y kromozomun yine babadan gelen normal Y kromozomun zigot sonrası endoredublikasyonundan kaynaklanabileceği tartıșılmıștır.

Anahtar sözcükler: Otistik olmayan super-erkek sendromu; 47, XYY karyotip; etkin-geçerli tanı

\section{INTRODUCTION}

The common aneuploidies include monosomy $\mathrm{X}$, trisomy 21 , trisomy 18 and trisomy13 and trisomy $\mathrm{Y}$ in human. While the autosomal aneuploidies cause serious malformations, but the sex chromosomal aneuploidies may cause less severe abnormalities ${ }^{1-4}$. The "gold standard" method for the detection of these autosomal and/or sex chromosal abnormalities of aneuploides is conventional cytogenetic analysis of phytohemagglutinin-stimulated

peripheral blood karyotype analysis. The $\mathrm{XYY}$ syndrome is common sex chromosomal abnormality that a prevalence of 1:1,000 live male births ${ }^{1,2}$. The majority of XYY males are phenotypically normal but there is seldom literature reports of variable autistic problems ${ }^{5-7}$. Several specific clinical features including mental retardation, psychiatric problems, skeletal abnormalities and behavioural problems have been reported in XYY syndrome ${ }^{8,9}$. In the current case report we aimed to show an adult boy in $47, \mathrm{XYY}$ without autistic problems.

\section{CASE REPORT}

The current case of 47,XYY syndrome was reported due to without autistic profiles such as language and social impairment. Twenty-nine years old presented infertile man has not been detected during childhood or even in the adulthood. He was performed on general average values on tests such as; language, cognitive ability, achievement, verbal memory, attention deficit, executive function, and motor function. He has features of tall stature, normal IQ and motor coordination and without genital anomalies. Automated karyotype analysis was made after combined methods with GTG, $\mathrm{C}$ bandings and FISH techniuqes for the current case. The proband's karyotype was determined as 47,XYY. Additional Y chromosome was identified after conventional GTG and Cbanded karyotype analysis and QF-PCR genotyping. No other numerical and/or structural chromosomal abnormalities were detected in the karyotype analysis. Cytogenetic methods combined with cost-effective techniques such as C, GTG banding and FISH provide well-define of extra Y chromosome, is effectively used in the worldwide and is also used in this presented of without autistic spectrum case study. Both Y chromosomes were observed in the same size and dimensions during the microscopic survey, the Cbanded profiles in the current proband pointed out that both are originated from one chromosome by endoreduplicatio of the $\mathrm{Y}$ chromosome after zigote formation. Conventional cytogenetic analysis of phytohemagglutininstimulated peripheral blood showed that $47, \mathrm{XYY}$ status in all 25 metaphases (Figure 1). 


\section{CMJ Case Report December 2016, Volume: 38, Number: 4}
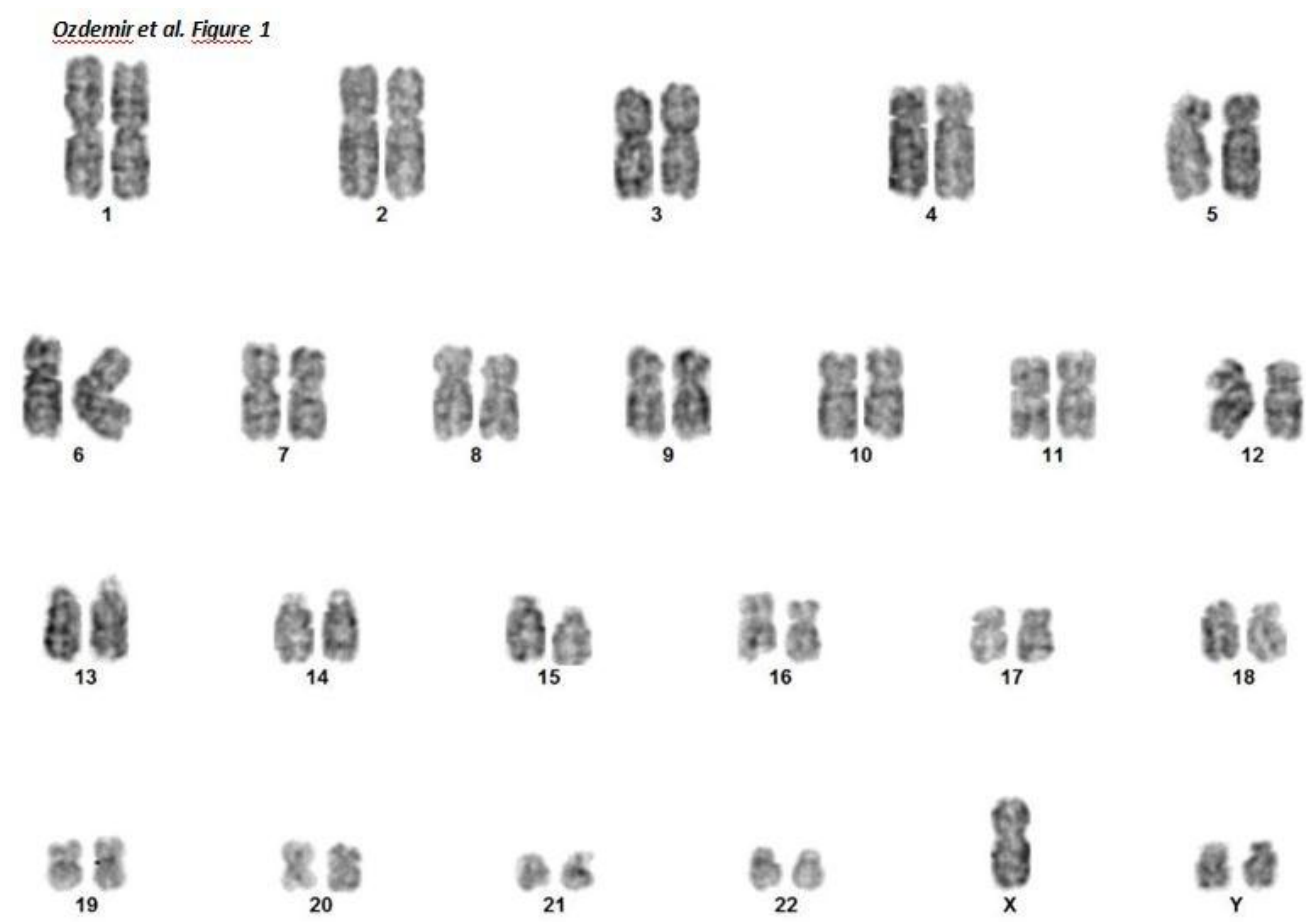

Figure 1. G-banded karyotype showing 48,XYY structure. The rest of all other chromosomoes are in normal appearance.

After conventional G-banding karyotype analysis, the additional $\mathrm{Y}$ chromosome was identified by fluorescence in situ hybridization (FISH) and C-banding techniques (Figure 2). Metaphase spreads were analysed by $\mathrm{Y}$ and $\mathrm{X}$ chromosomes specific centromeric fluorescence in situ hybridization (FISH) probes. In a total of twenty-five metaphase $(47, X Y Y)$ and interphase cells revealed DXZ1 $\times 1, \mathrm{DYZ} 1 \times 2$ signals profile after in situ hybridization analysis (Figure 3, A and B). After Cbanding technique two $\mathrm{Y}$ chromosomes were detected and totally the same $\mathrm{C}$ band positive (C-band+) profiles were detected in both $\mathrm{Y}$ chromosomes (Figure 1-3). Cytogenetic methods combined with FISH and C-banding can efficiently and cost-effective identify the origin of unknown chromosomes and provide accurate clues for clinical diagnosis. 


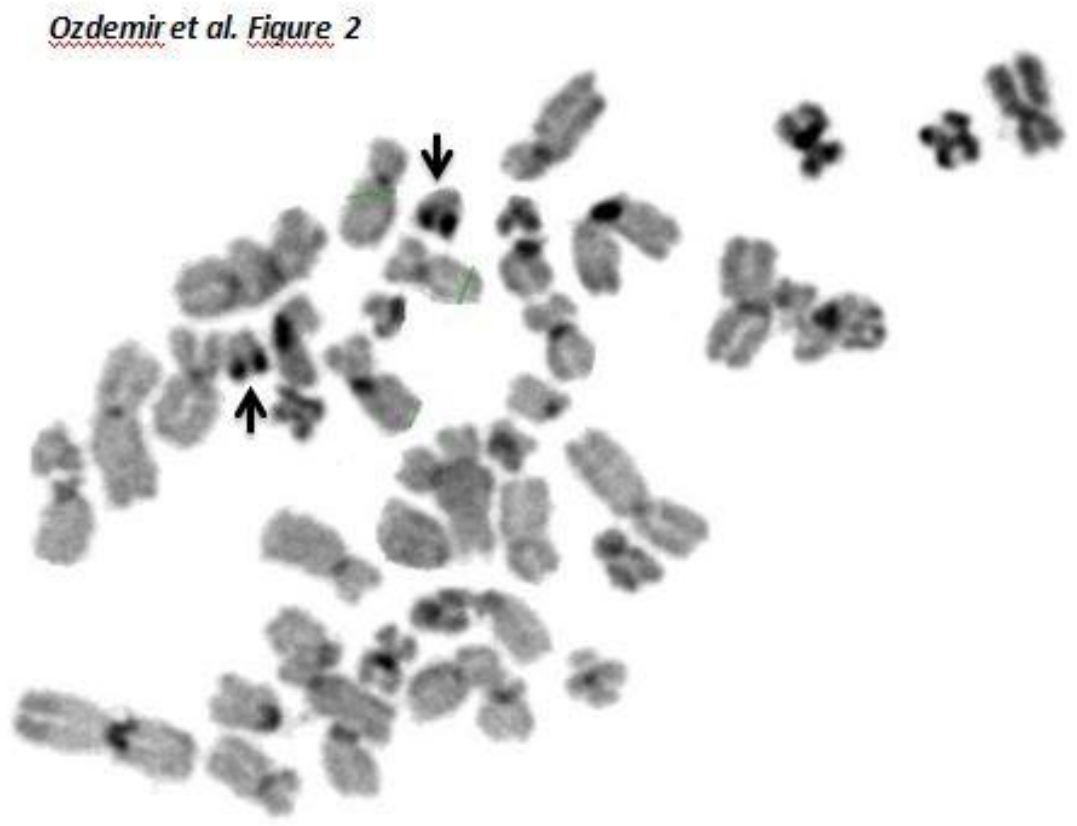

Figure 2.C-banded metaphase plate shows double Y chromosomes(arrows). Similar C band positive regions in $\mathrm{q}$ arms of $\mathrm{Y}$ chromosomes were detected in the presented case.

Ozdemir et al, Figure 3

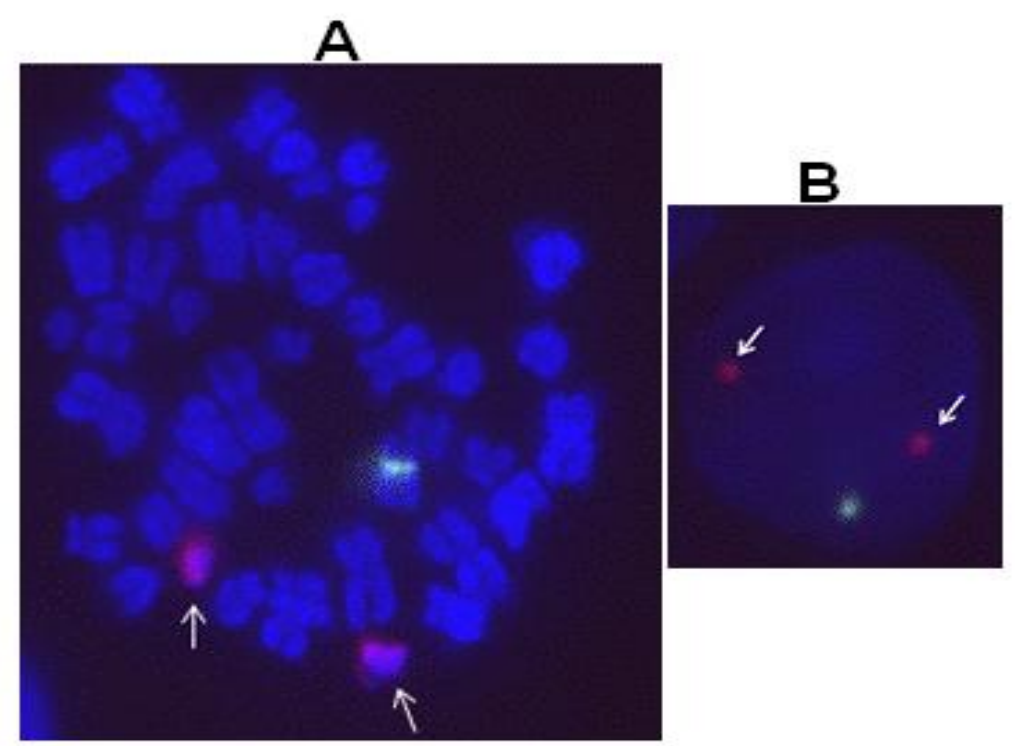

Figure 3. Fluorescence in situ hybridization analysis with centromeric probes of DXZ1 and DYZ3 (Vysis) for chromosomes X (green) and Y (red) showing the XYY profile of methaphese (A) and interphase(B) cell nuclei. Arrows indicate the Y chromosomes. 


\section{Ozdemir et al, Figure 4}

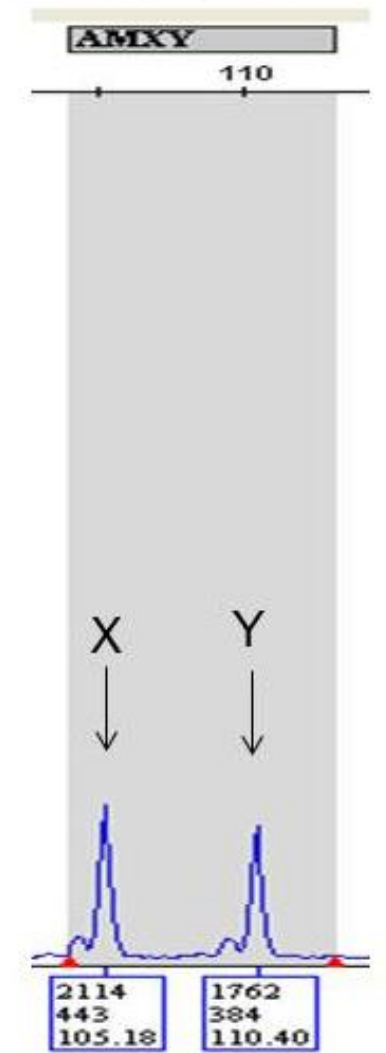

Figure 4. QF-PCR profile of $\mathrm{X}$ and $\mathrm{Y}$ chromosomes in the current infertile case. Arrow indicates the 1:1 ratio and false negativity.

\section{DISCUSSION}

Autosomal and sex chromosome aneuploidies occurred at meiosis 1 or post-zygotic stages after non-disjunction, by endoreduplication or anaphase lagging mechanisms. The nondisjunction of chromosome 21 during maternal meiosis I was reported as a cause of Down syndrome ${ }^{8}$. The $\mathrm{Y}$ chromosome aneuploidy is always from paternal origin and results from nondisjunction in the meiotic I division or post-zygotic mitosis by anaphase lagging and/or endoreduplication. Sex and autosomal chromosome abnormalities such as; trisomy 21, trisomy 13, trisomy 18, 47, XXY, 47 $\mathrm{XYY}, \quad 45, \mathrm{X} / 46, \mathrm{XY}$ mosaicism are frequently associated with ASD.
Basically, some autosomal and $\mathrm{X}$ chromosomes were considered important in the ASD due to autistic symptoms, but the Y chromosome predisposition has not been clearly explained, so far.

The current report explores an unmarried male with 47, XYY chromosome status and without any autistic problems. Results also showed that the FISH, Cbanding and quantitative fluorescent PCR is a fast and reliable method for detection of additional $\mathrm{Y}$ chromosome aneuploidies. In general, the majority of XYY males are phenotypically, normal but limited literature findings claimed the possible role of double $\mathrm{Y}$ chromosomes and autism ${ }^{10-13}$. The current case of $47, \mathrm{XYY}$ syndrome was reported due to without autistic profiles such as language 
and social impairment. Due to normal phenotype and lack of clinical symptoms, diagnosis of such patients may be difficult, especially if fertility is not compromised. This report re-emphasizes the critical role of karyotype analysis in young children with sex chromosome aneuploidies even if without typical phenotype findings. The current report also recommends the GTG, C bandings, QF-PCR and FISH methods as a cost effective well-define technique for extra Y chromosome detection. Case was referred to physicians and recommended for long-term follow-up.

\section{REFERENCES}

1. Nagy B, Nagy RG, Lazar L, Schonleber J, Papp C, Rigo J Jr.Detection of sex chromosome aneuploidies using quantitative fluorescent PCR in the Hungarian population.Clin Chim Acta. 2015 Mar 16; 445: 2-6.

2. Nguyen-Minh S, Bührer C, Hübner C, Kaindl AM.Is microcephaly a sofar unrecognized feature of XYY syndrome? Meta Gene 2014; 2: 1603.

3. He Y, Li X, Wang D, Zhang E, Hu Y, Wang W, Huang R, Xiao R.Acute promyelocytic leukaemia with a PML-RARA insertional translocation and a chromosome 21 abnormality in XYY syndrome: case report.J Int Med Res 2014; 42: 136373.

4. Dennis A, Howell S, Cordeiro L, Tartaglia N."How should I tell my child?" Disclosing the diagnosis of sex chromosome aneuploidies.J Genet Couns 2015; 24: 88-103.

5. Cianci V, Ferlazzo E, De Martino G, Vinci A, Gasparini S, Tripodi GG, Aguglia U.Continuous spikes and waves during slow sleep in a child with karyotype 47, XYY. Epileptic Disord 2014; 16: 223-6.

6. Margari L, Lamanna AL, Craig F, Simone M, Gentile M.Autism spectrum disorders in $\mathrm{XYY}$ syndrome: two new cases and systematic review of the literature.Eur J Pediatr 2014; 173: 277-83.
7. Kasparis C, Loffeld A.Childhood acne in a boy with XYY syndrome. BMJ Case Rep 2014; 2014. pii: bcr2013201587.

8. Ghosh D1, Sinha S, Chatterjee A, Nandagopal K.Discerning nondisjunction in Down syndrome patients by means of GluK1$($ AGAT)(n) and D21S2055(GATA)(n) microsatellites on chromosome 21. Indian J Hum Genet 2012; 18: 204-16.

9. Wade BS, Joshi SH, Reuter M, Blumenthal JD, Toga AW, Thompson PM, Giedd JN.Effects of sex chromosome dosage on corpus callosum morphology in supernumerary sex chromosome aneuploidies. Biol Sex Differ 2014; 5: 16.

10. Parihar M, Koshy B, Srivastava VM.Mosaic double aneuploidy: Down syndrome and XYY.Indian $\mathbf{J}$ Hum Genet 2013; 19: 346-8.

11. Nicolaides KH, Musci TJ, Struble CA, Syngelaki A, Gil MM.Assessment of fetal sex chromosome aneuploidy using directed cell-free DNA analysis.Fetal Diagn Ther 2014; 35: 1-6.

12. Fernández-Mayoralas DM, Fernández-Jaén A, FernándezPerrone AL.Expanding spectrum of electroclinical findings in patients with karyotype 47, XYY.Brain Dev 2014; 36: 413.

13. Shah AH, Manjunatha BS, Bindayel NA, Khounganian R. Oral health management of a patient with 47,XYY syndrome.BMJ Case Rep 2013, doi: $10.1136 /$ bcr-2013010408 . 